\title{
FOAMING CONTROL IN ACTIVATED SLUDGE TREATMENT PLANTS BY COAGULANTS ADDITION
}

\author{
D. MAMAIS* \\ E. KALAITZI \\ A. ANDREADAKIS
}

Received: 09/08/10

Accepted: 30/08/11

\author{
SEL, Sanitary Engineering Laboratory \\ School of Civil Engineering \\ National Technical University of Athens \\ Iroon Polytechniou 5, GR-15780 Zografou, Greece \\ *to whom all correspondence should be addressed: \\ e-mail: mamais@central.ntua.gr
}

\section{ABSTRACT}

This paper presents the results of an investigation that aimed to evaluate the efficiency of various inorganic coagulants and organic polymers to combat filamentous foaming and bulking problems, caused by the proliferation of M. parvicella and/or Gordona amarae.

The duration of the investigation covered 14 months. During this period foam samples were taken from the aeration basins of two full-scale wastewater treatment plants that contained high concentrations of $M$. parvicella and/or Gordona amarae. Bench scale batch experiments were conducted to evaluate the efficiency of the following coagulants: ferric chloride, ferrous chloride, polyaluminium chloride, hydrated aluminium sulphate, cationic polymer. In addition bench scale batch experiments (ammonia uptake rate (AUR) and oxygen uptake rate (OUR) measurements) were conducted to evaluate the toxicity effects of the most promising coagulants on nitrification and organic matter removal.

Polyaluminium chloride (PAX) and cationic polymer proved to be the most efficient among all the coagulants investigated. By adding PAX (aluminium application of $6.6-11.5 \mathrm{~g} \mathrm{Al}^{3+} \mathrm{kg}^{-1} \mathrm{MLSS}$ ) a general improvement of the settling properties of the activated sludge was achieved. High foaming control was also achieved with cationic polymer addition at doses in the 3.5 to $4.5 \mathrm{~g} \mathrm{~kg}^{-1} \mathrm{MLSS}$. According to microscopic analysis of the sludge samples following PAX or polymer addition, the floc strength was improved and flocs appeared more compact and dense. In addition both $M$. parvicella and Gordona amarae filamentous organisms were embedded inside the floc material, making access to particulate and colloidal substrates more difficult due to increased diffusional resistance.

PAX or polymer addition, at the above specified doses, resulted in a $75-100 \%$ reduction of the sludge foaming potential. PAX potential toxicity was investigated in the context of this study. PAX addition caused no inhibition on autotrophic and heterotrophic bacteria that perform nitrification and organic carbon removal, respectively. The estimated operational costs of PAX and polymer addition for foaming control, are approximately 0.0057 euros $\mathrm{m}^{-3}$ and 0.0026 euros $\mathrm{m}^{-3}$ of wastewater treated, respectively.

KEYWORDS: Foaming, bulking, coagulants, filamentous bacteria, Microthrix parvicella, Gordona amarae, control strategies, scum.

\section{INTRODUCTION}

Foaming and bulking problems in activated sludge wastewater treatment plants are associated with the presence of a variety of filamentous bacteria. The viscous brown foam resulting from the growth of these organisms, can create safety hazards, deteriorate effluent quality and be a source of odours. The most frequent filamentous microorganisms causing sludge foaming are Microthrix parvicella and Gordona amarae. Wastewater composition is one of the significant factors affecting 
foam formation, as it has been found that slowly degradable organic material and especially lipids favour the growth of both M. parvicella and G. amarae (Mamais et al., 1998; Jenkins et al., 1993).

Filamentous bulking and foaming can be controlled by specific strategies. These strategies are selectively targeted at achieving a proper composition of the sludge biocenoses that address the causes of the filamentous overabundance. Other means of achieving bulking and foaming control are non-specific methods that tend to alleviate the symptoms associated with the filamentous proliferation without though addressing the actual cause of the filamentous growth. Therefore specific control strategies are preferable as they are selective and they offer a permanent solution of the problem whereas non-specific methods tend to provide only temporary solutions.

Existing specific foaming control methods may be successful in some cases in alleviating severe foaming problems. However, especially for Microthrix parvicella, there are no reliable specific control methods that can be applied in all activated sludge systems that are experiencing foaming problems. For example reduction of sludge age may prove to be an efficient method to suppress $M$. parvicella growth (Noutsopoulos et al., 2006). However this method cannot be applied in activated sludge systems that must nitrify throughout the year and especially in winter, because the sludge age required to washout $M$. parvicella, may also eliminate nitrifying bacteria. Therefore non-specific methods are currently the only available strategies for effective foaming control that can be applied in all cases.

One of the most common non-specific methods for bulking control is the use of oxidizing chemicals such as chlorine. However chlorine addition for foaming control is not always successful. In many cases the high chlorine doses required cause floc break-up and may inhibit both nitrification and organic matter removal. Therefore alternative non-specific methods need to be developed to control filamentous foaming. For example a dose of $0.5 \mathrm{mg} \mathrm{l}^{-1}$ of a polyacrylamide cationic polymer has been proven to effectively eliminate Gordona amarae foaming problems in the aeration tank of an activated sludge plant (Shao et al., 1997). Recent attempts using polyaluminium chloride (PAX) have provided some promising results and PAX addition may prove to be an effective method of controlling filamentous foaming in activated sludge wastewater treatment plants in the future (Rossetti et al., 2005; Paris et al., 2005, Nielsen et al., 2005). Roels et al., (2002) reported a loss of surface scum following PAX addition at dosages ranging from 1.5 to $4.5 \mathrm{~g} \mathrm{Al}^{+3} \mathrm{~kg}^{-1}$ MLSS-day. Depending on the sludge age; the lower the sludge age the higher the dosage required. The exact mechanism of PAX foaming controlling mechanism is still largely unknown. Some hypotheses relate PAX addition to possible partial inhibition of the ability of $M$. parvicella to metabolize hydrophobic substrates, to a decrease in the hydrophobicity of activated sludge and to a better flocculation of activated sludge.

This paper presents the results of an investigation that aimed to evaluate the efficiency of various inorganic coagulants and organic polymers to combat filamentous foaming and bulking problems, caused by the proliferation of $M$. parvicella and/or Gordona amarae. Bench scale batch experiments were conducted to evaluate the efficiency of the following coagulants: ferric chloride, ferrous chloride, PAX, hydrated aluminium sulphate, cationic polymer. In addition bench scale batch experiments (ammonia uptake rate (AUR) and oxygen uptake rate (OUR) measurements) were conducted to evaluate any potential toxicity effects of the most promising inorganic coagulants on nitrification and organic matter removal. No toxicity experiments were performed with polymers because addition of cationic organic polymers is not expected to cause toxic effects on activated sludge cultures.

\section{EXPERIMENTAL MATERIALS AND METHODS}

Bench scale batch experiments were conducted in order to evaluate the efficiency of each coagulant to control foaming and bulking problems. The duration of the experiments was 14 months, from June 2005 to August 2006. During this period foam samples were taken from the aeration basins of two full-scale wastewater treatment plants that contained high concentrations of $M$. parvicella and/or Gordona amarae with a frequency ranging from $4-5$ (scale $0-5$ ). Both treatment plants are nutrient removal activated sludge systems operating at a sludge age of approximately $7-8$ days. The batch experiments were conducted with $1 \mathrm{I}$ foam samples diluted at a concentration of $7000 \pm$ $1000 \mathrm{mg} \mathrm{l}^{-1}$. Coagulants were dosed at various concentrations and then the sample was intensively mixed for 5 minutes. Following mixing, the efficiency of each coagulant at a specific dose, was determined by microscopic evaluation of the activated sludge prior and following coagulant addition, 
by measuring the foaming propensity of the activated sludge and by diluted sludge volume index (DSVI) measurements.

All analyses were in accordance with the Standard Methods (1994); DSVI values were measured in unstirred 1 I cylinders. Microscopic examination of the sludge samples was performed according to to Eikelboom and van Buijsen (1981). Foaming capacity of the samples was assessed using a modification of the foaming test developed by Pitt and Jenkins (1990). According to the original foaming test, a mixed liquor sample was taken from the aeration basin, diluted with distilled water at a mixed liquor suspended solids (MLSS) concentration of $2000 \mathrm{mg} \mathrm{l}^{-1}$. A $250 \mathrm{ml}$ volume of the diluted sample was then transferred to an ethanol washed and dried 1 I graduated cylinder fitted with an airstone at the bottom. The sample was spurge with $\mathrm{N}_{2}$ gas for 2 minutes at a flow rate of 1600 $\mathrm{cm}^{3} \mathrm{~min}^{-1}$. Foaming potential is equal to the height of the foam layer reached during the test. In order to increase the sensitivity of the foaming test the following changes were made: the duration of the test was 7 min instead of 2 min, the target suspended solids concentration was $7000 \mathrm{mg} \mathrm{l}^{-1}$ instead of $2000 \mathrm{mg} \mathrm{I}^{-1}$ and the volume of the sludge sample was $500 \mathrm{ml}$ instead of $250 \mathrm{ml}$. In addition to the foaming potential, the amount of solids that tend to foam was also determined as the difference between the suspended solids concentration in the mixed liquor at the start and at the end of the aeration period.

In addition bench scale batch experiments, ammonia uptake rate (AUR) and oxygen uptake rate (OUR) measurements, were conducted according to Kristensen et al. (1992), to evaluate the toxic effects of the most promising coagulants on nitrification and organic matter removal.

\section{RESULTS}

\section{Bench Scale Batch Experiments}

Bench scale batch experiments were conducted in order to evaluate the efficiency of each coagulant in controlling foaming and bulking problems. The efficiency of each coagulant was determined by microscopic evaluation of the activated sludge prior and following coagulant addition, by measuring the foaming propensity of the activated sludge and by DSVI measurements. DSVI measurements are not shown in this paper because DSVI values appeared to be approximately constant irrespective of the dose of coagulant added. This response was attributed to the relatively good settling characteristics of the activated sludge used, with DSVI values in the $100-180 \mathrm{ml} \mathrm{g}^{-1} \mathrm{SS}$ range.

During the bench scale batch experiments the following coagulants were evaluated:

- Ferrous chloride $\left(\mathrm{FeCl}_{2}, \mathrm{Fe}^{2+}\right.$ concentration $=8,85 \%$ on a $\mathrm{w} / \mathrm{w}$ basis, trade name $=$ Ferrosol 9)

- Ferric chloride $\left(\mathrm{FeCl}_{3}, \mathrm{Fe}^{3+}\right.$ concentration $=12,93 \%$ on a w/w basis, trade name $=$ Ferrisol $\mathrm{Cl}$ 130)

- Hydrated aluminium sulphate $\left(\mathrm{Al}_{2}(\mathrm{SO} 4)_{3} \cdot 14 \mathrm{H}_{2} \mathrm{O}, \mathrm{Al}^{3+}\right.$ concentration $=5,15 \%$ on a w/w basis, trade name $=$ Alusol 30)

- Polyaluminium chloride low basicity $\left(\mathrm{Al}_{n}(\mathrm{OH})_{3 \mathrm{~m}} \mathrm{Cl}_{3 n-\mathrm{m}}, \mathrm{Al}^{3+}\right.$ concentration $=5,4 \%$ on a w/w basis, $\mathrm{pH}=2.7$, trade name $=$ PAC $\mathrm{B} 40)$

- Polyaluminium chloride high basicity $\left(\mathrm{Al}_{\mathrm{n}}(\mathrm{OH})_{3 \mathrm{~m}} \mathrm{Cl}_{3 \mathrm{n}-\mathrm{m}}, \mathrm{Al}^{3+}\right.$ concentration $=5,1 \%$ on a w/w basis, $\mathrm{pH}=3.0$, trade name $=$ PAC B70)

- Cationic polymer (medium molecular weight with a high degree of cationic charge).

Foam samples were taken from two full-scale treatment plants in Greece. As shown in Table 1 all foam samples taken, contained high concentrations of $M$. parvicella and/or Gordona amarae with a filament index $(\mathrm{FI})$ ranging from $4-5$ (scale $0-5,0=$ none, $5=$ overabundance). Based on the results of the bench scale experiments the dose of each coagulant in $\mathrm{g} \mathrm{kg}^{-1}$ of mixed liquor suspended solids (MLSS), required to decrease the foaming propensity of the activated sludge samples by $80 \%$, was determined (Table 2). Polyaluminium chloride and cationic organic polymer proved to be the most efficient among all coagulants investigated, with effective doses ranging from $6-11 \mathrm{~g} \mathrm{Al}^{+3} \mathrm{~kg}^{-1} \mathrm{MLSS}$ and $3.5-4.5 \mathrm{gr} \mathrm{kg}^{-1} \mathrm{MLSS}$, respectively. 
Table 1. Dominant filamentous organisms and filament index $(\mathrm{FI})$ in foaming activated sludge samples employed in this study

\begin{tabular}{|c|c|c|c|}
\hline Sampling period & $\begin{array}{c}\text { Sampling } \\
\text { place }\end{array}$ & $\begin{array}{c}\text { M. parvicella and G. } \\
\text { Amarae content }\end{array}$ & $\begin{array}{c}\text { Filament Index } \\
(0=\text { none, 5= overabundance })\end{array}$ \\
\hline Phase 1: & WWTP 1 & G. amarae & 4,5 \\
May - June 2005 & & M. parvicella & 1,0 \\
\hline Pjase 2: & WWTP 1 & G. amarae & 4,0 \\
March - April 2006 & & M. parvicella & 2,0 \\
\hline Phase 3: & WWTP 2 & M. parvicella & 5,0 \\
May - June 2005 & & G. amarae & 3,5 \\
\hline Phase 4: & WWTP 1 & G. amarae & 4,0 \\
May - June 2005 & & M. parvicella & 3,5 \\
\hline Phase 5: & WWTP 2 & M. parvicella & 3,5 \\
June - July 2006 & & G. amarae & 3,5 \\
\hline
\end{tabular}

Table 2. Coagulant dose required to achieve an $80 \%$ reduction of foam propensity

\begin{tabular}{|c|c|c|} 
Type of coagulant & $\begin{array}{c}\text { Dose required to achieve an } \\
80 \% \text { reduction of the total } \\
\text { volume of foam produced during } \\
\text { the foam test } \\
\left(\mathrm{g} \mathrm{kg}^{-1} \mathrm{MLSS}\right)\end{array}$ & $\begin{array}{c}\text { Dose required to achieve an } \\
80 \% \text { reduction of the } \\
\text { suspended solids that tend } \\
\text { to accumulate in the foam } \\
\left(\mathrm{g} \mathrm{kg}^{-1} \mathrm{MLSS}\right)\end{array}$ \\
\hline $\mathrm{FeCl}_{2}$ & 30 & 35 \\
\hline $\mathrm{FeCl}_{3}$ & 25.6 & 34.2 \\
\hline $\mathrm{Al}_{2}(\mathrm{SO} 4)_{3} .14 \mathrm{H}_{2} \mathrm{O}$ & 30 & 26 \\
\hline $\mathrm{PAC} \mathrm{B} 40$ & 11.0 & 10.5 \\
\hline PAC $\mathrm{B} 70$ & 6.6 & 11.5 \\
\hline Cationic polymer & 4.4 & 3.5 \\
\hline
\end{tabular}

Ferrous chloride addition at doses as high as $20 \mathrm{~g} \mathrm{Fe}^{2+} \mathrm{kg}^{-1} \mathrm{MLSS}$, caused no more than $50 \%$ reduction in foaming potential. Similarly ferric chloride addition at doses that exceeded $20 \mathrm{~g} \mathrm{Fe}^{3+} \mathrm{kg}^{-1}$ MLSS resulted in a $50 \%$ reduction of the sludge foaming potential. Significant foaming control was achieved only at high doses of ferrous and ferric chloride addition, equal to approximately $32.5 \mathrm{Fe}^{2+}$ $\mathrm{kg}^{-1} \mathrm{MLSS}$ and $29.9 \mathrm{Fe}^{3+} \mathrm{kg}^{-1} \mathrm{MLSS}$, respectively. Similarly, low foaming control efficiency was also obtained with aluminium sulphate addition.

Polyaluminium chloride and cationic polymer proved to be the most efficient among all the coagulants investigated. By adding polyaluminium chloride (aluminium application of $6.6-11.5 \mathrm{~g}$ $\mathrm{Al}^{3+} \mathrm{kg}^{-1}$ MLSS) a general improvement of the settling properties of the activated sludge was achieved. High foaming control was also achieved with cationic polymer addition at doses in the 3.5 to $4.5 \mathrm{~g} \mathrm{~kg}^{-1} \mathrm{MLSS}$ range. According to the microscopic analysis of the sludge samples following PAX or polymer addition, the floc strength was improved and flocs appeared more compact and dense. As illustrated in Figures 1 and 2 filament index decreased from $4.5-5$ to approximately $3-3.5$. Addition of any of these coagulants resulted in larger flocs, most of them having a diameter greater than $150 \mu \mathrm{m}$. In addition both M. parvicella and G. amarae filamentous organisms were embedded inside the floc material.

Figures 3 and 4 illustrate the effect of PAX addition on the sludge foaming propensity determined as the maximum volume reached by the expanding foam and as the amount of solids that tend to foam. PAX doses in the range between $6.6-11.5 \mathrm{~g} \mathrm{Al}^{+3} \mathrm{~kg}^{-1} \mathrm{MLSS}$ resulted in a $75-100 \%$ reduction of the sludge foaming potential. As shown in Figures 5 and 6 , high foaming control was also observed with cationic polymer addition at doses that range from 3.5 to $4.5 \mathrm{gr} \mathrm{kg}^{-1} \mathrm{MLSS}$. 


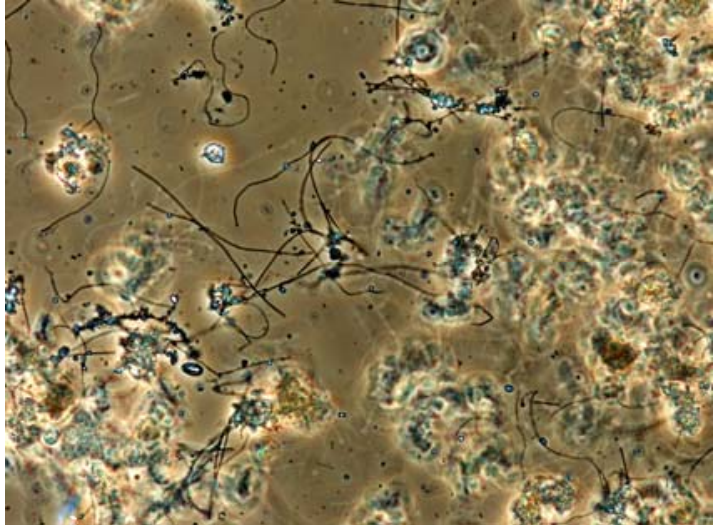

Figure 1. Activated sludge before addition of PAX (magnification X 100) FI = 4.5

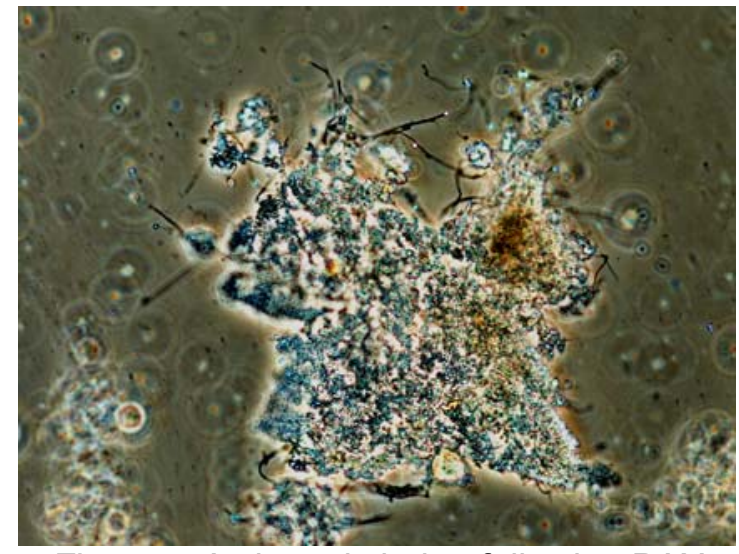

Figure 2. Activated sludge following PAX addition (magnification X 100) FI = $3-3.5$

According to the results of this study, it appears that PAX and cationic polymer addition changes the morphological characteristics of $M$. parvicella and Gordona amarae filamentous organisms, improving flocculation significantly. This is probable due to the neutralization of negative surface charged particles (including M. parvicella and G. amarae) found in mixed liquor by addition of positively charged coagulants. Minimization of negatively charged particles results in better flocculation and allows activated sludge flocs size to increase. Additionally, negatively charged anionic surfactants and biosurfactants that are produced by foaming forming bacteria (Pagilla et al., 2002) tend to enhance and stabilize foam (Ho and Jenkins, 1991). The addition of positively charged flocculation agents will tend to neutralize these surfactants and minimize their foam stabilizing effect. In the case of cationic polymer bridging mechanism should also enhance flocculation. The overall positive effects of improved flocculation are: 1) most of $M$. parvicella and Gordona amarae filamentous organisms are trapped within the flocs, making access to colloidal substrates and lipids more difficult due to increased diffusional resistance and 2) M. parvicella and Gordona amarae filamentous organisms are embedded within the flocs and removed by excess sludge. Therefore they are not able to form foam and to accumulate in the activated sludge system.

Similar findings can be found in the literature for foaming control. Paris et al. (2005) conducted laboratory scale continuous flow activated sludge experiments to investigate means of controlling foam due to excessive M. parvicella growth. By dosing PAX $\left(3.5 \mathrm{Al}^{3+} \mathrm{g} \mathrm{kg}^{-1} \mathrm{MLSS}\right.$ day $\left.^{-1}\right)$ a general improvement of the settling and foaming characteristics of the sludge was achieved. PAX addition resulted in a lower $M$. parvicella occurrence and decreased hydrophobicity and floating tendency of activated sludge. Similarly Roels et al. (2002) based on operational data from several full-scale activated sludge treatment plants reported a loss of surface scum following PAX addition. In fact Roels et al. (2002) developed the following equation to establish the required PAX dose for foaming control as a function of the solids retention time (SRT):

$60 / S R T=\# \mathrm{Al}^{3+} \mathrm{g} \mathrm{kg}^{-1} \mathrm{MLSS}$

According to eq. (1) the recommended dose for achieving foaming control is approximately $7.5 \mathrm{~g} \mathrm{Al}^{+3}$ $\mathrm{kg}^{-1}$ MLSS, a value approximately $25 \%$ lower than the average dose determined according to the batch experiments presented in this paper. This difference is attributed to the fact that the batch experiments conducted within the context of this study aimed to evaluate one of the effects of PAX addition to activated sludge which is the overall flocculation improvement. According to the literature though, Nielsen et al. (2005), apart from the flocculation effect, PAX exerts an inhibiting effect on foaming causing bacteria and especially on $M$. parvicella. PAX addition is reported to attack the ability of this bacterium to use lipids by decreasing the activity of exoenzymes such as lipase. Therefore, PAX addition for foaming control in an activated sludge system should expected to have a twofold effect on foaming control namely to improve flocculation and to partially inhibit substrate uptake by M. parvicella. 


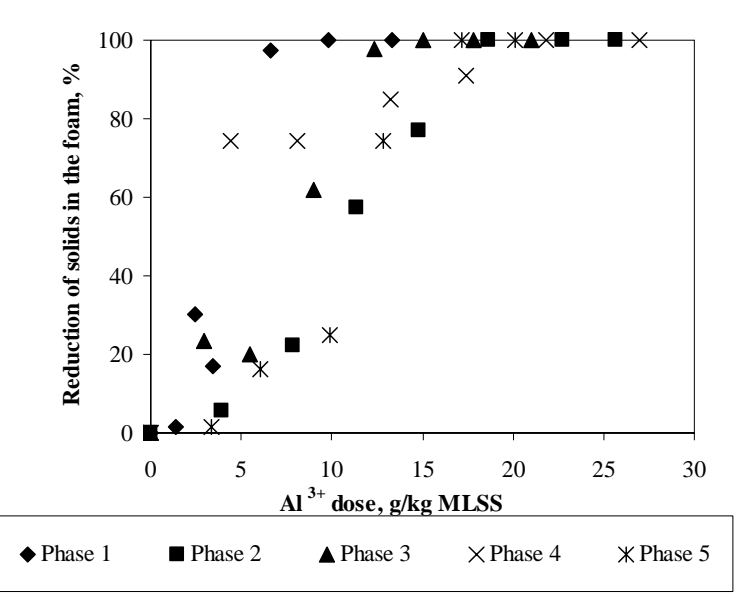

Figure 3. Reduction of the amount of solids that tend to create foam as a function of PAX addition

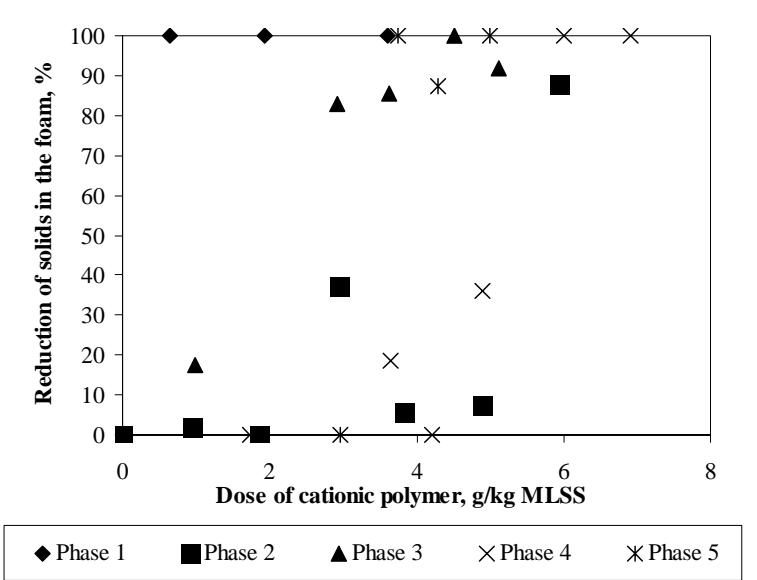

Figure 5. Reduction of the amount of solids that tend to create foam as a function of cationic polymer addition

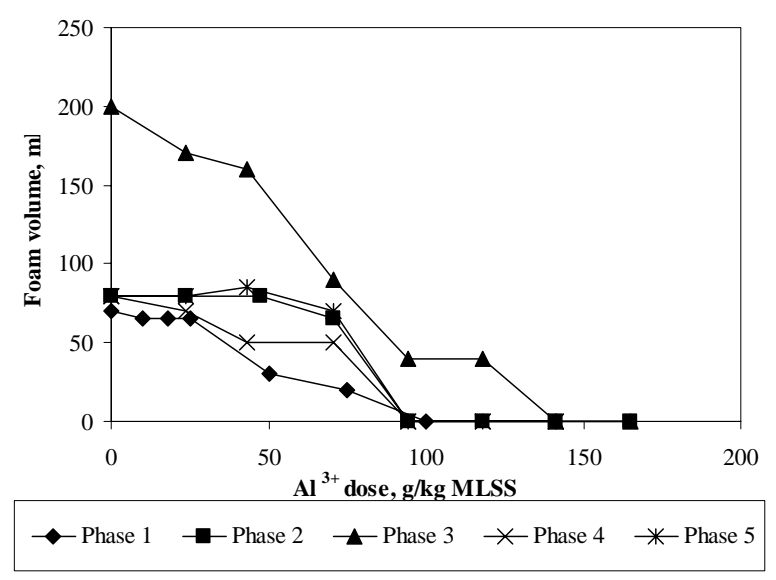

Figure 4. Foam produced during the foaming test as a function of PAX addition

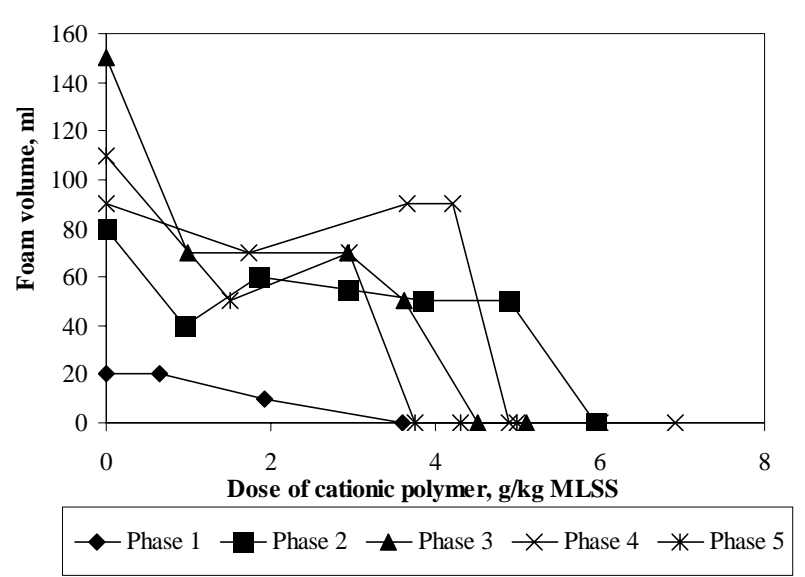

Figure 6. Foam produced during the foaming test as a function of cationic polymer addition

\section{Economic evaluation of coagulant addition for foaming control}

A final assessment of the use of coagulants for foaming control should take into account other issues related to the operation of a WWTP such as chemical costs and additional sludge produced. In this paragraph an economic evaluation of the most promising coagulants for foaming control is attempted. The economic evaluation comprised of the following elements: chemicals cost and additional sludge treatment and disposal cost. The coagulants included in this evaluation were ferric chloride, PAX with high basicity and cationic polymer. According to Table 2, target values for foaming control for the three coagulants are $29.9 \mathrm{~g} \mathrm{Fe}^{3+} \mathrm{kg}^{-1} \mathrm{MLSS}, 9 \mathrm{~g} \mathrm{Al}^{3+} \mathrm{kg}^{-1} \mathrm{MLSS}$ and $4 \mathrm{~g}$ polymer $\mathrm{kg}^{-1} \mathrm{MLSS}$, respectively. The economic evaluation was performed for a medium size WWTP with an average treatment capacity of $10,000 \mathrm{~m}^{3}$ day $^{-1}$, operating at solids residence time of 8 days, a hydraulic residence time of 0.333 days, and an MLSS concentration of $3500 \mathrm{mg} \mathrm{l}^{-1}$.

Chemicals cost: The cost of ferric chloride, PAX or polymer addition was estimated by assuming that all the chemicals added are sorbed on activated sludge. This assumption was verified my measuring soluble aluminium concentration, following addition of PAX and mixture with activated sludge. The measurements showed that the effluent soluble $\mathrm{Al}^{3+}$ concentration was consistently below $20 \mathrm{\mu g} \mathrm{I}^{-1}$.

In order to estimate the cost of PAX addition to maintain a target dose of $9 \mathrm{~g} \mathrm{Al}^{3+} \mathrm{kg}^{-1} \mathrm{MLSS}$ the following equation was applied that was derived by conducting an aluminium mass balance around the activated sludge system: 
$[\mathrm{Al}]_{\text {aeration basin }}=(\mathrm{SRT}) / \mathrm{HRT}{ }^{*}[\mathrm{Al}]_{\text {wastewater }}$

where:

SRT $=$ solids residence time $=8$ days

$\mathrm{HRT}=$ hydraulic residence time in the aeration basin $=0.333$ days

$[\mathrm{Al}]_{\text {aeration basin }}=$ concentration of $\mathrm{Al}^{3+}$ in the aeration basin $\left(\mathrm{mg} \mathrm{Al}^{+3} \mathrm{I}^{-1}\right)$

$[\mathrm{Al}]_{\text {wastewater }}=$ concentration of $\mathrm{Al}^{3+}$ in the wastewater following PAX addition $\left(\mathrm{mg} \mathrm{Al}^{+3} \mathrm{I}^{-1}\right)$

For an MLSS concentration of $3500 \mathrm{mg} \mathrm{l}^{-1}$ the target $\mathrm{Al}^{3+}$ concentration in the aeration basin should be $31.5 \mathrm{mg} \mathrm{l}^{-1}$. Following eq. (2) we can calculate that the $\mathrm{Al}^{3+}$ concentration in the influent wastewater is equal to approximately $1.3 \mathrm{mg} \mathrm{I}^{-1} \mathrm{Al}^{3+}$. According to the above for an average flow of $10,000 \mathrm{~m}^{3}$ day $^{-1}$ the daily consumption of $\mathrm{Al}^{+3}$ is in the order of $13 \mathrm{~kg} \mathrm{Al}^{3+}$ day $^{-1}$. Assuming that the cost of commercial PAX solution $\left(5.1 \% \mathrm{Al}^{3+}\right.$ on a w/w basis) is approximately 270 euros/tonne, the cost of PAX addition is approximately 51 euros/day or 0.0051 euros $\mathrm{m}^{-3}$ of wastewater treated.

Similar calculations were performed to estimate the cost of ferric chloride and polymer addition. According to eq. (2) $\mathrm{Fe}^{3+}$ and polymer concentrations in the influent wastewater were found equal to approximately $4.4 \mathrm{mg} \mathrm{l}^{-1}$ and $0.6 \mathrm{mg} \mathrm{l}^{-1}$, respectively. Therefore for an average flow of $10,000 \mathrm{~m}^{3} \mathrm{~d}^{-1}$ the daily consumption of $\mathrm{Fe}^{3+}$ or cationic polymer is equal to $44 \mathrm{~kg} \mathrm{~d}^{-1}$ and $5.8 \mathrm{~kg} \mathrm{~d}^{-1}$, respectively. Assuming that the cost of ferric chloride commercial solution $\left(12.9 \% \mathrm{Fe}^{3+}\right.$ on a w/w basis) is 200 euros/tonne, the daily cost of ferric chloride addition, is approximately 68 euros/day or 0.0068 euros $\mathrm{m}^{-3}$ of wastewater treated. Similarly for a polymer cost of 4.5 euros $\mathrm{kg}^{-1}$ the daily cost of cationic polymer addition, is approximately 26 euros/day or 0.0026 euros $\mathrm{m}^{-3}$ of wastewater treated.

Additional Sludge Production: Sludge volume and quantity is expected to increase by the addition of PAX or ferric chloride. The increase in total suspended solids concentration was calculated by measurement of suspended solids concentration before and after inorganic chemicals addition and was found to average approximately $3.3 \mathrm{grSS} \mathrm{gr}^{-1} \mathrm{Al}^{3+}$ and $2.0 \mathrm{grSS} \mathrm{gr}^{-1} \mathrm{Fe}^{3+}$ added, respectively. No measurable increase in solids concentration was obtained with organic polymer addition. Therefore no significant chemical sludge production is anticipated with polymer addition.

Table 3 presents chemical addition and sludge treatment and disposal costs for each coagulant studied. Based on data for medium size WWTPs provided by Mamais et al. (2009), sludge treatment and disposal cost was considered equal to 140 euros/tonne of DS. According to the cost analysis conducted polymer addition appears to be the most cost-effective method for foaming control with total operational cost equal to 26 euros/day or 0.0026 euros $\mathrm{m}^{-3}$. Application of PAX had the lower operational cost compared to the other inorganic coagulants studied with a total cost of 57 euros/day or 0.0057 euros $\mathrm{m}^{-3}$.

Table 3. Assessment of operational cost for coagulant addition for foaming control

\begin{tabular}{|c|c|c|c|}
\hline Type of coagulant & $\begin{array}{c}\text { Chemical addition } \\
\text { Cost, euros } \mathrm{d}^{-1}\end{array}$ & $\begin{array}{c}\text { Chemical sludge } \\
\text { treatment and disposal } \\
\text { cost, euros day }\end{array}$ & $\begin{array}{c}\text { Total operational cost, } \\
\text { euros day }^{-1}\end{array}$ \\
\hline $\mathrm{FeCl}_{3}$ & 68 & 12.3 & 80.3 \\
\hline PAC B70 & 51 & 6 & 57 \\
\hline Cationic polymer & 26 & 0 & 26 \\
\hline
\end{tabular}

\section{Toxicity Assessment Batch Experiments}

Bench scale AUR and OUR batch experiments were conducted, according to Kristensen et al. (1992), to evaluate the toxicity of PAX addition to nitrification and organic matter removal. The experiments were conducted employing PAX doses in the range from $0-14 \mathrm{~g} \mathrm{Al}^{+3} \mathrm{~kg}^{-1} \mathrm{MLSS}$, or respectively from $0-100 \mathrm{Al}^{+3} \mathrm{mg} \mathrm{l}^{-1}$. Activated sludge samples were taken from WWTP 1 that performed nitrification throughout the year. AUR and OUR batch measurements are shown in Tables 4 and 5 , respectively. According to the data obtained, PAX addition at the above doses caused no inhibition on nitrification and organic carbon removal. No toxicity experiments were performed with cationic polymers because addition of cationic polymers is expected to cause no toxic effects on activated sludge cultures. 
Table 4. Toxicity assessment of PAX addition to nitrifying activated sludge using AUR tests

\begin{tabular}{ccccc}
\hline \multirow{2}{*}{$\begin{array}{c}\text { PAX } \\
\text { addition } \\
\left(\left.\mathrm{mg} \mathrm{Al}^{+3}\right|^{-1}\right)\end{array}$} & \multicolumn{2}{c}{ PAX low basicity (PAC B40) } & \multicolumn{2}{c}{ PAX high basicity (PAC B70) } \\
\cline { 2 - 5 } & $\begin{array}{c}\text { AUR } \\
\left(\mathrm{mg} \mathrm{NO}_{3}-\mathrm{N} \mathrm{g}^{-1} \mathrm{VSS} \mathrm{hr}^{-1}\right)\end{array}$ & $\begin{array}{c}\text { Nitrification } \\
\text { inhibition } \\
(\%)\end{array}$ & $\begin{array}{c}\text { AUR } \\
\left(\mathrm{mg} \mathrm{NO}_{3}-\mathrm{N} \mathrm{g}^{-1} \mathrm{VSS} \mathrm{hr}^{-1}\right)\end{array}$ & $\begin{array}{c}\text { Nitrification } \\
\text { inhibition } \\
(\%)\end{array}$ \\
\hline 0 & 2.2 & 0 & 1.7 & 0 \\
\hline 25 & 2.0 & 8.2 & 1.6 & 6 \\
\hline 50 & 2.2 & 0 & 1.7 & 0 \\
\hline 100 & 2.2 & 0 & 1.9 & 0 \\
\hline
\end{tabular}

Table 5. Toxicity assessment of PAX addition to heterotrophic activated sludge using OUR tests

\begin{tabular}{ccccc}
\hline \multirow{2}{*}{$\begin{array}{c}\text { PAX } \\
\text { addition } \\
\left(\mathrm{mg} \mathrm{Al}^{+3} \mathrm{I}^{-1}\right)\end{array}$} & $\begin{array}{c}\text { PAX low basicity (PAC B40) } \\
\text { OUR }\end{array}$ & $\begin{array}{c}\text { Organic } \\
\text { carbon } \\
\text { removal } \\
\text { inhibition } \\
(\%)\end{array}$ & $\begin{array}{c}\text { PAX high basicity (PAC B70) } \\
\left(\mathrm{mg} \mathrm{O}_{2}-\mathrm{g}^{-1} \mathrm{gSS} \mathrm{hr}^{-1} \mathrm{VSS} \mathrm{hr}^{-1}\right)\end{array}$ & $\begin{array}{c}\text { Organic carbon } \\
\text { removal } \\
\text { inhibition } \\
(\%)\end{array}$ \\
\hline 0 & 18.1 & 0 & 14.4 & 0 \\
\hline 25 & 19.2 & 0 & 15.3 & 6 \\
\hline 50 & 17.8 & 2 & 15.6 & 0 \\
\hline 100 & 18.8 & 0 & 14.6 & 0 \\
\hline
\end{tabular}

\section{CONCLUSIONS}

The main conclusions of the present work can be summarised in the following:

- Polyaluminium chloride (PAX) and cationic polymer proved to be the most efficient among all the coagulants investigated. By adding polyaluminium chloride (aluminium application of $6.6-$ $11.5 \mathrm{~g} \mathrm{Al}^{3+} \mathrm{kg}^{-1} \mathrm{MLSS}$ ) or cationic polymer (polymer doses in the 3.5 to $4.5 \mathrm{gr} \mathrm{kg}^{-1} \mathrm{MLSS}$ range) a general improvement of the settling properties of the activated sludge was achieved. According to the microscopic analysis of the sludge samples following coagulants addition, the floc strength was improved and flocs appeared more compact and dense. In addition both $M$. parvicella and Gordona amarae filamentous organisms were embedded inside the floc material, making access to particulate and colloidal substrates more difficult due to increased diffusional resistance.

- According to AUR and OUR experiments, PAX addition at the above doses caused no inhibition on autotrophic and heterotrophic bacteria that perform nitrification and organic carbon removal, respectively.

- The increase in sludge production by PAX addition was found to average approximately 3.3 grSS gr $^{-1} \mathrm{Al}^{+3}$ added.

- No measurable increase in sludge production was obtained with cationic polymer addition.

- The cost of PAX addition for foaming control comprising of chemical cost and additional sludge treatment and disposal cost is estimated to be approximately 0.0057 euros $\mathrm{m}^{-3}$ of wastewater treated.

- Cationic polymer addition was shown to be the most cost-effective method for foaming control. The cost of cationic polymer addition is estimated to be approximately 0.0026 euros $\mathrm{m}^{-3}$ of wastewater treated.

\section{ACKNOWLEDGMENTS}

The work presented in this paper was partly funded by the Joint Venture for the Design and Construction of $2^{\text {nd }}$ Phase Psyttalia Biological Treatment Works. 


\section{REFERENCES}

APHA - WEF - AWWA (1992), Standard Methods for Water and Wastewater Laboratory Analysis.

Eikelboom D.H. and van Buijsen H.J.J. (1981), Microscopic sludge investigation manual, Delft: IMG-TNO, Report A94a.

Ho C.F. and Jenkins D. (1991), The effect of surfactants on Nocardia foaming in activated sludge, Wat.Sci.Tech., 23, 879-880.

Jenkins D., Richard M.G. and Daigger G.T. (1993), Manual on the causes and control of activated sludge bulking and foaming, 2nd Edition, Lewis Publishers, USA.

Kristensen G.H., Jorgensen P. and Henze M. (1992), Characterization of functional microorganism groups and substrate in activated sludge and wastewater by AUR, NUR and OUR, Wat. Sci. Tech., 25(6), 43-57.

Mamais D., Andreadakis A., Noutsopoulos C. and Kalergis C. (1998), Causes of and Control Strategies for Microthrix parvicella Bulking and Foaming in Nutrient Removal Activated Sludge Systems, Wat.Sci.Tech., 37(4/5), 9-17.

Mamais D., Tzimas A., Efthimiadou A., Kissandrakis J. and Andreadakis A. (2009), Evaluation of Different Sludge Mechanical Dewatering Technologies, Journal of Residuals Science and Technology, 6(1), $27-34$.

Nielsen P.H., Kragelundc, Nielsen J.L., Tiro S., Lebek M. (2005), Control of microthrix parvicella in activated sludge plants by dosage of polyaluminium salts: Possible Mechanisms, Acta hydrocim. Hydrobiol., 33(3), 255-261.

Noutsopoulos C., Mamais D. and Andreadakis A. (2006), Effect of solids retention time on Microthrix parvicella growth, Water SA, 32, 3, 315-321.

Pagilla K.R., Sood A. and Kim H. (2002), Gordonia (Nocardia) amarae foaming due to biourfactant production, Wat.Sci.Tech., 46(1/2), 519-524.

Paris S., Lind G. Lemmer H. and Wilderer P.A. (2005), Dosing aluminum chloride to control of Microthrix parvicella, Acta hydrocim. Hydrobiol., 33(3), 247-254.

Pitt P. and Jenkins D. (1990), Causes and control of Nocardia in activated sludge, Research Journal WPCF, 62 (2), 143-150.

Roels T., Dauwe F., Van Damme S., De Wilde K. and Roelandt F. (2002), The influence of PAX-14 on activated sludge systems in particular on Microthrix parvicella, Wat.Sci.Tech., 46(1/2), 487-490.

Rossetti S., Tomei M.C., Nielsen P.H. and Tandoi V. (2005), Microthrix parvicella, a filamentous bacterium causing bulking and foaming in activated sludge systems: a review of current knowledge, FEMS Microbiology Reviews, 29(1), 49-64.

Shao Y.J., Starr M., Kaporis K., Kim H.S., Jenkins D. (1997), Polymer Addition as a Solution to Nocardia Foaming Problems, Water Environmental Research, 69(1), 25-27. 